\title{
МОВНА ІДЕНТИЧНІСТЬ ЕТНІЧНИХ СПІЛЬНОТ У КОНТЕКСТІ УКРАЇНСЬКОЇ МОВНОЇ СИТУАЦЇ̈
}

\author{
ОКСАНА МИХАЛЬЧУК \\ Інститут мовознавства ім. О.О. Потебні НАН України, Київ - Україна \\ oksmykhalchuk@gmail.com; ORCID 0000-0001-9278-9341
}

\section{TOŻSAMOŚĆ JĘZYKOWA WSPÓLNOT ETNICZNYCH W KONTEKŚCIE UKRAIŃSKIEJ SYTUACJI JĘZYKOWEJ}

\author{
OKSANA MYCHALCZUK \\ Instytut Językoznawstwa im. O.O. Potebni Narodowej Akademii Nauk Ukrainy, Kijów - Ukraina
}

\begin{abstract}
STRESZCZENIE. Niniejsze badanie określa główne parametry socjolingwistyczne zbiorowej tożsamości językowej. Rozważana jest rola takich konstruktów, jak etniczność, państwowość, wartość językowa oraz kulturowa w kształtowaniu tożsamości językowej. Podejście do analizy zostało wybrane z uwzględnieniem posttotalitarnej specyfiki sytuacji językowej w Ukrainie. W badaniu została podjęta próba prześledzenia korelacji między etnolingwistyczną a narodową tożsamością językową. Zostały przeanalizowane takie determinanty, jak status językowy, witalność języka, socjolingwistyczna siła społeczności i wsparcie instytucjonalne. Podkreśla się znaczenie zarządzania i planowania językowego w kraju oraz nowatorskie zasady europejskiej polityki językowej (tolerancja językowa, integracja językowa, ochrona zagrożonych języków, zwrócenie szczególnej uwagi na prawa językowe) jako punkty odniesienia dla skupienia się na językowej tożsamości społeczności etnicznych. Proponuje się teoretyczne uzasadnienie pojęć tożsamość etnolingwistyczna i narodowa (państwowa) tożsamość językowa.
\end{abstract}

Słowa kluczowe: tożsamość językowa, integracja językowa, zarządzanie językiem, planowanie językowe, społeczność językowa 


\title{
LANGUAGE IDENTITY OF ETHNIC COMMUNITIES IN THE CONTEXT OF UKRAINIAN LANGUAGE SITUATION
}

\author{
OKSANA MYKHALCHUK \\ O.O. Potebnia Institute of Linguistics of the National Academy of Science of Ukraine, \\ Kyiv - Ukraine
}

\begin{abstract}
The article outlines the main sociolinguistic parameters of collective language identity. The role of such constructs as ethnicity, statehood, linguistic and cultural value is considered in terms of the formation of language identity. The approach to the analysis here was chosen with taking account of the post-totalitarian specifics of the language situation in Ukraine. The correlation between ethnolanguage and national language identity has been traced. Determinants such as language status, language vitality, sociolinguistic capacity of communities and institutional support are taken into consideration. The importance of language management and language planning in the country and innovative principles of European language policies (language tolerance, language integration, preservation of endangered languages and emphasis on language rights) are underlined as points of reference for focusing on the language identity of ethnic communities. Theoretical substantiation of the concepts "ethnolinguistic identity" and "national (state) language identity" is offered.
\end{abstract}

Keywords: language identity, language integration, language management, language planning, language community

$\mathrm{H}$

аукові підходи до вивчення й аналізу різних видів ідентичностей є актуальними і дискусійними в гуманітарних науках упродовж десятиліть. Множинність предметного поля, поєднання та різновекторність підходів (примордіалізму, інструменталізму, конструктивізму, есенціалізму тощо) до трактування цього поняття зумовлює також його динаміку та мінливість, однак не заперечує того, що в багатьох контекстах опису розмаїття довкілля, зокрема мовного, без поняття ідентичності сьогодні важко обійтися. Особливої уваги заслуговує зміст категорії мовна ідентичність. При аналізі цього виду ідентичності особливо важливими є міркування Дж. Фішмана, що одні й ті ж суспільства можуть використовувати різну логіку щодо мовної ідентичності залежно від історичного періоду розвитку своєї нації [Fishman 2020].

Осердям поняття мовна ідентичність є кореляція зв’язків мови та інших видів ідентичностей (етнічної, національної, територіальної). Змістове наповнення категорії „мовна ідентичність” також тісно пов’язане з геополітичною ситуацією. в контексті викликів сучасного світу - з одного боку, глобалізація і мобільність, з іншого - збереження мовного розмаїття - актуалізуються потреби соціолінгвістичного аналізу мовної ідентичності в контексті різних мовних ситуацій. 
Мета нашого дослідження - увиразнити соціолінгвістичні аспекти категорії „мовна ідентичність” та акцентувати увагу на проблемних питання спільнотних типів колективної мовної ідентичності в контексті сучасної мовної ситуації України.

Актуальність дослідження зумовлена також поширенням в сучасній гуманітаристиці категорії ,етномовна ідентичність” та потреби осмислення їх у зв'язку з поняттями „мовна ідентичність”, „мовна ідентифікація”, „етнічна ідентичність”, „етномовна спільнота”, „мовна самоідентифікація” „загальнонаціональна мовна ідентичність” з погляду сучасної соціолінгвістики. Соціолінгвістичний аналіз принципів колективної мовної ідентичності з урахуванням посттоталітарної специфіки українського суспільства може стати інструментом для формування мовного менеджменту й мовного планування в країні та підгрунтям для запобігання кризи мовної та етнічної ідентичностей.

Дослідження предметної сфери мовної ідентичності в українському мовознавстві особливо активізувалися упродовж останніх десятиріч. в сучасній українській соціолінгвістиці аналіз поняття мовна ідентичність найбільшою мірою презентований у дослідженнях, що стосуються мовної самоідентифікації та самовизначення (О. Руда, Н. Шумарова, Л. Масенко, Р. Олексенко, Ю. Ситник), вивчення ролі мови в конструюванні різних видів ідентичностей (Я. Радевич-Винницький, М. Гончарова), впливу мовної політики та мовного планування на становлення мовної та національної ідентичності (Б. Ажнюк, Г. Мацюк, Л. Масенко, О. Чередниченко). Увага до мовної ідентичності як маркера національної самобутності чи етнічної спільноти активно пролонговується в студіях з етнології, соціальної психології, етнополітики, геополітики, соціології.

У соціолінгвістичній перспективі проглядаються принаймні чотири рівні мовної ідентичності: 1) мовна ідентичність держави (загальнонаціональна мовна ідентичність); 2) мовна ідентичність територій (певних історико-етнічних регіонів); 3) мовна ідентичність етнічних груп чи спільнот; 4) мовна ідентичність особи. Підходи та методології для визначення чи виокремлення цих ідентичностей не завжди матимуть послідовно ідентичний характер. Самі ж рівні мовної ідентичності є своєрідною мережею вузлів, кожен із яких відокремлений та пов'язаний з іншим одночасно. Також роль соціальних, політичних, етнічних, психологічних конструктів мовної ідентичності має різну силу впливу на становлення й репрезентацію колективних та індивідуальних ії виявів.

Коротко розглядаємо два типи колективної (спільнотної) мовної ідентичності: загальнонаціональну (державну) та етномовну, а також зв'язки між ними. Ці типи мовної ідентичності розкриваються насамперед через такі категорії соціолінгвістики, як мовна політика, статус мови, соціолінгвістичний портрет мови, мовна спільнота / група, престиж мови та мовне законодавство. Спільнотна ідентичність, на відміну від індивідуальної, визначається через 
універсальні характеристики, кількісні та якісні показники і є менш динамічною.

При розгляді цього питання виходимо $з$ того, що 1) мовна ідентичність $€$ частиною державної ідентичності і недооцінювання цього сегменту неминуче призводить до кризи загальнонаціональної (державної) ідеї; 2) співіснування різних рівнів спільнотних ідентичностей в межах держави побудоване за ієрархічним принципом; 3) мовна ідентичність етнічних спільнот $є$ складником мовної ситуації і важливою ланкою в моделях мовного планування. Також враховуємо думку, що в різних геополітичних ситуаціях мову можуть використовувати ,як інструмент державотворення i, навпаки, державоруйнування" [Демська, Мальцев 2016: 16]. Держава як результат і як інструмент мовної ідентичності зобов'язана гарантувати збереження мовної ідентичності для кожної з етнічних спільнот (в тому числі титульної) і створити умови для інтеграції представників меншинних мовних спільнот та груп в загальнонаціональний мовний простір.

У більшості європейських країн віддзеркаленням ідентичності держави $€$ мовна ідентичність. Експерти Венеційської комісії щодо мовних політик висловлюють позицію, що саме „підтримка державної мови гарантує розвиток ідентичності державної спільноти" [Ажнюк 2019: 31], а громадяни не $\epsilon$ вільними від обов' язку володіти державною мовою. Як зауважує Б. Ажнюк, ця думка збігається з положенням статті 4.1 „Загальної декларації мовних прав” (1996), де наголошується, що „особи, які переїжджають і оселяються на території іншої мовної спільноти, мають право і обов'язок інтегруватися в цю спільноту" [Ажнюк 2019: 32]. Тому критеріями мовної політики національної держави $є$ принцип державності мови титульної нації та принцип територіальності, коли мова $є$ колективним ідентифікатором держави, тієї спільноти громадян, що проживають на території країни. Така колективна мовна ідентичність автоматично переноситься на індивідуальну ідентичність 3 позиції спостерігача. Теоретично вважають, що кожен громадянин України розмовляє українською, Польщі - польською, Франції - французькою і т.д. У контексті парадигми держава-мова для національних держав такий принцип стає домінантною ознакою мовної ідентичності держави. Звісно, це менше стосується держав з федеральним устроєм. Попри одномовність більшості європейських країн, у них також діють законодавчі акти, що регулюють використання мов меншин.

Присутність меншинних чи міноритарних мов (польської, румунської, гагаузької чи караїмської в Україні, кашубської чи української в Польщі, ельзаської, берберської чи баскської у Франції тощо) у структурі мовної ідентичності держави є ознакою мовної розмаїтості, показником належності частини населення до етнічної чи етномовної спільноти чи групи і в ієрархічній 
структурі мовної ідентичності держави корелює зі статусними та соціолінгвістичними характеристиками відповідної спільноти.

Україна з огляду на етнічну структуру населення (за переписом 2001 року $77,8 \%$ громадян етнічні українці) в контексті теорії мовної ідентичності (кількість представників певного етносу дорівнює кількості мовців) належить до типу одномовних нащіональних держав з високим коефіцієнтом мовної ідентичності, коли нація, етнос, мова, держава перебувають в одній площині і взаємодоповнюють одне одного, а в мовній практиці громадян збігаються: державна мова, мова повсякденного спілкування, етнічна мова (вона ж найчастіше самовизначається як рідна) [Михальчук 2015: 284-285]. Однак етнічна структура й етномовна структура українського суспільства значно відрізняються. Про це свідчать принаймні такі факти: $62,5 \%$ білорусів, $83 \%$ євреїв, 88,5\% греків, 64,7\% німців, 58,7\% татар 30,3\% болгар, що мешкають в Україні, назвали рідною російську мову; 71\% українських поляків назвали рідною українську мову, 15,6\% - російську, і тільки 13,4\% - польську [Масенко 2010: 116]. Ще складнішою є картина, коли йдеться про мовну практику. Згідно з переписом 2001 р., українську мову вважали рідною 67,5\%, мову своєї національності вважають рідною $85,2 \%$ українців. При цьому у повсякденному житті громадяни України користуються майже порівно: відповідно $63,1 \%$ обирають українську, а $63,7 \%$ - російську. Кількість осіб, що визнали рідною не українську і не російську - 1,4\%, У виборі повсякденного спілкування цей відсоток майже наполовину нижчий. Проте соціологічні дослідження засвідчують, що через 5 років після перепису 2006 року збільшилася кількість осіб української та інших національностей, зокрема білорусів, євреїв, циган, німців, які вважають рідною українську мову [Огульчанський 2008: 27]. Нові геополітичні реалії, „популярність” пошуку прив’язаності до етнічних коренів, що була нівельована в СРСР, має значний вплив на мовну самовизначеність. Часто це зумовлене престижем і статусом відповідної мови на міжнародній арені, підтримкою меншинних етнічних спільнот країнами-метрополіями. На динаміку мовного самовизначення вказують деякі локальні дослідження. Однак вони часто мають спорадичний характер. Гадаємо, загальномасштабне дослідження, зокрема новий перепис, показало б сьогодні дещо яснішу цілісну картину.

Мовна ситуація впливає на стан і якість загальнонаціональної мовної ідентичності і виявляє наслідки зміщення ієрархії ідентичностей в ланцюгу державна мова - меншинна мова. Засобом для стабілізації зазвичай стає законодавство. Перед законодавством як державним механізмом стоїть завдання виплекати (акумулювати) загальнонаціональну мовну ідентичність, де мова титульної нації є маркером національної держави, а більші й менші етномовні спільноти зберігатимуть власну самобутність та власні мовні уподобання. 
Природне право законодавчо закріпити за мовою титульного народу статус державної мови вперше було зреалізоване 28 жовтня 1989 р. в законі УРСР Про мови в Украӥнській РСР, 1992 році - закріплене Конституциією України. Бурхливі дискусії навколо проєктів мовних законодавств, Закону України Про засади державної мовної політики (2012), чинного мовного закону Про забезпечення функиіонування украӥнської мови як державної (2018), попри різні перипетії щодо статусу регіональних та офіційних мов, не піддавали сумніву статус державності української мови.

Статусне утвердження української мови як державної супроводжувалося пошуком засобів міжкультурного діалогу з етнонаціональними меншинами. Провідним орієнтиром для їхнього вирішення був зарубіжний досвід вибудовування системи толерантних відносин у поліетнічному суспільстві [Якубова 2019: 111]. Ратифікації Свропейської хартії регіональних або міноритарних мов, поява Всесвітньої декларації мовних прав та звернення національних мовнополітичних практик до Загальноєвропейських рекомендацій з мовної освіти стають підгрунтям для основ мовної політики більшості європейських національних держав, в тому числі України. Однак мобільність, глобалізація, нові інформаційні технології та політичні умови породжують нову ієрархію мов у мовній свідомості суспільства. Такі конструкти мовної ідентичності, як етнічність, державність, лінгвокультурна цінність мови частково нівелюються зростанням ваги комерційної вартості мов та політичних маніпуляцій. За цих умов гармонійний територіальний чи колективний мультилінгвізм залишається уявленням романтиків, бо ця гармонія ніколи не буде позбавлена конкурентності. Природна конкуренція мов провокує появу мовних та етнічних конфліктів, в основі яких часто дежить криза мовної ідентичності. Джерелом цієї кризи є змішання етносів, претензії до мовних територій, міграції тощо. Зокрема, посягання на чужі території супроводжується ідентифікаиією цих територій з мовним простором. Інноваційні принципи мовних політик (мовна толерантність, збереження загрожених мов, акценти на мовні права) покликані відшукати нові підходи для формування та збереження мовної ідентичності національних держав та окремих етнічних спільнот. Водночас актуальною залишається практична необхідність мовної адаптації національних меншин, передусім представників меншинних етномовних спільнот чи груп, в загальнонаціональний мовний простір.

Відмінності якісних та кількісних параметрів етнічних спільнот (компактність чи дисперсність проживання, кількість носіїв мови, підтримка мовними метрополіями, мовно-культурна та інформаційна інфраструктура тощо), наслідки радянської ідеології із синдромом посттоталітарної радянської ідентичності (часто як „розчинення в російськомовній поліморфній масовій культурі” [Якубова 2019: 112], а подекуди і саме ставлення етнічних спільнот до власної мови (як зауважує Б. Ажнюк, „доводиться стикатися з тим, 
що сама етномовна спільнота не завжди виявляє зацікавленість у збереженні своєї мови" [Ажнюк 2010: 53], - ускладнюють утвердження й збереження локальних мовних ідентичностей. Особливо це стосується чисельно невеликих мовних спільнот та загрожених мов.

Натомість боротьба за мовну ідентичність на мовному полі України розгорнулася між найбільшими мовними спільнотами - українськомовною та російськомовною. Українськомовна ідентичність є одночасно загальнонаціональною. Її зброєю також залишається: 1) кількісна перевага етнічних представників (загалом майже $80 \%$ ); 2) статус української мови як державної; 3) боротьба мовних активістів з наслідками тривалого зросійщення нації та за функціональність української мови у відповідних сферах суспільного життя. Російськомовна спільнота найбільш етнічно розмаїта, розбіжність між етнічністю й мовою $€$ ключовою рисою цієї спільноти в Україні. До неї належать етнічні росіяни, значна частина представників інших етнічних спільнот та етнічних українців, велика кількість нових мігрантів. Згідно з соціолінгвістичними опитуваннями, значна частина практичних російськомовців самоідентифікують себе з іншою мовою, насамперед через маркери етнічності. Проте за плечима російськомовної спільноти залишається власне мовна ситуаиія в краӥні, що заражена вірусом постколоніального впливу, який посилюється мовними агресіями Роciї, де в програмах для підтримки політики просування російської мови не останню роль відіграє проєкт „Русский мир” та мобілізація російської мови „як «м'якої сили» для збереження й нарощування свого впливу на сусідні країни” [Мацюк 2019: 227, 239]. Мовна ситуація в Україні стала плацдармом, на якому зручно маніпулювати мовою та ідентичністю. Тому в сучасній Україні пошук мовного облаштування з метою збереження мовної ідентичності російськомовної спільноти має проходити через мережу інтеграційних шляхів у загальнонаціональний контекст української держави. Це стане запорукою збереження загальнонаціональної (загальноукраїнської) ідентичності і - як показує досвід - територіальної цілісності країни. Тому правові заходи щодо російської мови повинні базуватися на ставленні до російської мови як 1) мови етнічної російської меншини; 2) мови колишнього тоталітарного режиму і мови держави-мовного агресора; 3) як до мови мігрантів. Власне тільки в першому пункті інституційні заходи щодо цієї мовної спільноти збігаються з основними законодавчими засадами та зобов'язаннями щодо мов національних меншин.

Якість мовної ідентичності етнічних спільнот України простежується через критерій мовної стійкості при самоідентифікації з рідною мовою. Найвищий рівень У 2001 р. виявили росіяни - 95,9\%, угорці - 95,4\%, кримські татари $-92 \%$, румуни -91,7\%. Майже половина представників 18 найбільших етнічних спільнот України (зокрема, євреї, греки, поляки, німці, білоруси) 2001 року не вважають рідною мову свого етносу [Етнонаціональна структура... 2004]. 
Серед меншинних етнічних спільнот з високим рівнем мовної стійкості (окрім російської) переважають спільноти з компактністю проживання. Мовна ідентичність цих спільнот підтримується законодавчими ініціативами, зокрема ратифікацією Свропейської хартії..., законами Про національні меншини ..., міжнародними та міжвідомчими договорами, угодами про співпрацю в сфері культури тощо. Важливу роль відіграє офіційна мовна підтримка держав-метрополій. Саме така підтримка особливо помітна в пошуках власної мовної ідентичності для польської спільноти. в радянський період ця спільнота зазнала структурних змін через переселення, $є$ частково розпорошена й асимільована. Підтримка Польщі, міжнародна співпраця на офіційному рівні, повернення релігійних споруд, можливості підвищення мовної компетенції для етнічних поляків тощо помітно сприяють зростанню потужності польськомовної спільноти в Україні.

Мовна ідентичність кримських татар як корінного народу України законодавчо підтримувалася від початку незалежності України. Специфіка та мовна історія кримських татар є темами окремих досліджень. Зауважимо лише, що високий рівень мовної стійкості, компактність проживання до 2014 року, офіційний статус мови в АР Крим сприяли активізації й стабілізації мовної ідентичності спільноти, кодифікаційному статусу мови. Наразі тимчасова окупація, часткова розпорошеність в різних середовищах створюють додаткові перепони для підтримки етномовної ідентичності кримських татар.

Мовна ідентичність невеликих етнічних спільнот найчастіше грунтується на ставленні до мови як до лінгвокультурної цінності, джерела етнічної ідентичності. В українському контексті кримськотатарська, кримчацька, караїмська і гагаузька, на відміну від інших етнічних спільнот, не мають держав-метрополій, де б ці мови були домінантними. Тому підтримка мовної ідентичності цих спільнот є особливо актуальною в контексті європейської мовної політики підтримки загрожених мов.

Побудова ідеальної мовної картини з урахуванням „капіталу мовного розмаїття світу" (за Блером Рублом) часто нівелюється різними позамовними чинниками, в тому числі відсутністю чіткої демаркації мовних спільнот в окремих регіонах, зокрема через значну кількість ситуативних білінгвів. Аналізуючи мовну ситуацію, О. Медвєдєв підсумовує, що „українське суспільство складається з трьох великих мовних спільнот: українськомовних, російськомовних і білінгвів" [Медведєв 2010]. Проте практичне використання двох чи кількох мов представниками різних мовних спільнот не є підставою для виділення їх в окрему мовну спільноту в контексті мовної ідентичності. Хоч індивідуальний білінгвізм впливає на усвідомлення й стабільність мовної ідентичності особи як представника певної мовної (мовних) спільнот, впливає на етномовну структуру суспільства і на стабільність мовної ідентичності територій, суб'єктом колективної мовної ідентичності залишається мовна 
cniльнота, яку, за В. Лабовим, не завжди визначає спільна мовна поведінка, а радше сукупність спільних норм, які простежуються в їхній оцінній поведінці [Labov 2020: 20].

Мовна ідентичність етнічної спільноти близька до такого виду колективної ідентичності, як етнічна, що базується на „відчутті належності до певної етнічної чи мовної спільноти, однаковості з іншими їі членами, наявністю відповідних емоційних зв'язків тощо" [Соціологія... 2006: 117]. Таким чином, колективна етномовна ідентичність (мовна ідентичність етнічних спільнот) - це спосіб збереження своєї мовної унікальності в територіальному загальнонаціональному мовному просторі. Стабільність і потужність цієї ідентичності лежить в основі якісних та кількісних характеристик самої спільноти та правових засад національної держави.

Окрім умов для збереження мовної ідентичності етнічних спільнот, держава зобов'язана гарантувати інтеграцію в загальнонаціональний простір, в тому числі мовний простір державної мови. Мовна інтеграція в цьому контексті є інструментом для збереження й цілісності мовної ідентичності держави. Вона не означає мовну асиміляцію, розчинення етномовних спільнот у єдиному мовному просторі - це суспільний принцип державної єдності, який не заперечує присутність і визнання відмінної від загальнонаціональної (державної) мовної ідентичності для мовних спільнот, груп чи окремих індивідів [Михальчук 2019: 314].

Часто етномовну ідентичність розглядають як складник етнічної ідентичності спільноти [Кухарук 2020], але з огляду на характеристики колективної ідентичності кореляція взаємозв'язків між етнічністю та мовою не завжди паритетна й перебуває в координатах соціолінгвістичних ознак етнічної спільноти. Попри те, якщо розглядати етномовну ідентичність як складник етнічної ідентичності поза принципом територіальності, домінантну ознаку нації в глобальному контексті, поза межами конкретної держави, це поняття узагальнюється і втрачає таку ознаку, як локальність. Водночас загальнонаціональна (державна) мовна ідентичність збігається з етномовною У зв'язку мова титульного етносу - мова держави. Зокрема, „мова й далі залишається запорукою виживання українського етносу як колективної індивідуальності" [Ажнюк 2019: 28] та одночасно є фактором єдності й національної безпеки України.

Загальнонаціональна (державна) мовна ідентичність прив'язана до території та інституційного статусу мови і є колективною мовною ідентичністю громадян, мовною ідентичністю країни. Етномовну ідентичність можна розглядати у вужчому і ширшому значеннях: 1) мовна ідентичність етномовних спільнот, мова яких відмінна від загальнодержавної і $є$ виразником їхньої самобутності на окремо взятій території, локальна; 2) колективна мовна ідентичність певного етносу в глобальному контексті, що символізує мовну єд- 
ність певної нації. Основною відмінною ознакою етномовної ідентичності $\epsilon$ принцип спадковості мов, природних колективних мовних прав на мову. Колективна етномовна ідентичність (на відміну від індивідуальної) не може сформуватися на основі вивчення мови, це завжди поєднується 3 наявністю й вітальністю етносу. Загальнонаціональна мовна ідентичність пов'язана з етнічним принципом опосередковано, основними координатами цього виду мовної ідентичності є статус мови та правовий статус - громадянство.

Віднайдення балансу між загальнонаціональною та етномовною ідентичністю $є$ одним із пріоритетів мовної політики, що базується на вже згаданих основних європейських засадах мовного планування. Важливим етапом мовного облаштування в цьому контексті є підготовка й ухвалення законодавства, яке б не тільки забезпечувало й регулювало використання мов національних меншин, а убезпечувало й передбачало ризики. Тому перед мовною політикою України поставлено завдання 1) збереження мовної ідентичності нації як запоруки національної цілісності; 2) захисту мовної ідентичності етнічних спільнот з метою підтримки загрожених мов. Сьогодні це завдання потребує свіжих ідей теорії мовного менеджменту та аналізу статусного мовного планування і забезпечення функцій присутніх У мовному просторі України мов відповідно до статусу, вітальності й престижу.

\section{Список використаної літератури}

Ажнюк Б.М., „Всесвітня декларація мовних прав”: украӥнський контекст, [в:] „Соціолінгвістичні студії”, заг. ред. Л. Ставицької, зб. наук. праць, Київ: Видавничий дім Дмитра Бураго, 2010, с. 51-57.

Ажнюк Б.М., Критерії оцінювання мовної політики, [в:] „Мовне законодавство і мовна політика: Україна, Європа, світ", зб. наук. праць, Київ: Видавничий дім Дмитра Бураго, 2019, с. 25-50.

Гончарова М., Роль мови У формуванні різновидів ідентичностей, [в:] „Мова і суспільство", 2015, вип. 6, с. 60-69.

Демська О., Мальцев Е., Мовна політика: про ідентичність і успішність У глобальному cвimi, [в:] „Мова: класичне-модерне-постмодерне”, ред. Л. Масенко, зб. наук, праць, Київ: Дух і літера, 2016, вип. 2, с. 16-26.

Етнонаціональна структура украӥнського суспільства, Київ: Наукова думка, 2004.

Кухарук О.Ю., Особливості етнічної ідентичності представників різних етномовних груп українського студенства, кваліфікаційна наукова праця на правах рукопису, Київ 2020.

Ляхович Г.В., Варіації на тему мовної ідентифікації та мовної ідентичності: множинність теоретичних інтерпретацій, [в:] Електронний ресурс: http:// npchdusoc_2015_258_246_16(23.10.2020). 
Масенко Л.Т., Нариси з соціолінгвістики, Київ: Вид. дім „Києво-Могилянська академія”, 2010.

Мацюк Г., Розвиток теорії сучасної соціолінгвістики: формування змісту поняття „інституиійний мовний менеджмент”, [в:] „Мова і суспільство”, Львів 2013, вип. 4, c. $12-32$.

Мацюк Г., Статус і функиії російської мови в Російській Федераиії, на пострадянському nросторі й у світі: стан і перспективи розвитку, [в:] „Мовне законодавство і мовна політика: Україна, Європа, світ”, зб. наук. праць, Київ: Видавничий дім Дмитра Бураго, 2019, с. 213-240.

Медведєв О., Мовний баланс Украӥни-2, Київ: б. в., 2010.

Михальчук О., Етномовна самоідентифікачія: сочіолінгвістичні параметри і якісний стан, [в:] „Українське мовознавство”, 2015, вип. 45/1, с. 281-287.

Михальчук О., Етномовні спільноти в Україні: інтеграція в загальнонаціональний контекст, [в:] „Мовне законодавство і мовна політика: Україна, Європа, світ”, зб. наук. праць, Київ: Видавничий дім Дмитра Бураго, 2019, с. 307-319.

Огульчанський Ю., Етнічна структура українського суспільства: уявні та дійсні проблеми, Київ: Вид. дім „Києво-Могилянська академія”, 2008.

Олексенко Р., Ситник Ю., Мовна ідентичність як засіб самовизначення та самоідентифікації в умовах посттоталітарного суспільства, [в:] Електронний ресурс: http:// nbuv.gov.ua/UJRN/upo_2017_1_4 (25.11.2020).

Радевич-Винницький Я.К., Мовна складова національного буття: студї̈ з української лінгвонаціології, Київ; Дрогобич: Посвіт, 2013.

Рубл Б., Капітал розмаїтости, Київ: Критика, 2007.

Соиіологія: словник термінів і понять, упоряд. Біленький Є.А. та ін., Київ: Кондор, 2006.

Чередниченко О., Національно-мовна ідентичність У глобальному світі, [в:] „Екологія мови і мовна політика в сучасному світі”, ред. Б. Ажнюк та ін., зб. наук праць, Київ: Видавничий дім Дмитра Бураго, 2012, с. 40-50.

Шумарова Н. П., Етномовна ідентифікація з погляду соиіолінгвістики, [в:] „Життя У слові”, зб. наук. праць на пошану академіка В.М. Русанівського, Київ: Видавничий дім Дмитра Бураго, 2011, с. 353-359.

Якубова Л., Національні меншини Украӥни: пошуки місия в модерному украӥнському проекті, [в:] „100-річчя державного органу з питань етнополітики в незалежній Україні як історія захисту національних меншин: державні інституції та міжнаціональні відносини - досвід виклики, завдання”, зб. наук. матеріалів, Київ: Дух і літера, 2019, c. $91-113$.

Fishman J., Endangered Minority Languages: Prospects for Sociolinguistic Research, [в:] Електронний ресурс: https://citeseerx.ist.psu.edu/viewdoc/download?doi=10.1.1.519.6918\&r ep=rep1\&type $=\operatorname{pdf}(25.11 .2020)$.

Labov W., Sociolinguistic Patterns, [в:] Електронний ресурс: https://books.google.com. ua/books/about/Sociolinguistic_Patterns.html?id=hD0PNMu8CfQC\&redir_esc =y (23.11.2020). 


\section{Spysok vykorystanoi literatury [References]}

Azhniuk B.M., „Vsesvitnia deklaratsiia movnykh prav”: ukrainskyi kontekst [,, Universal Declaration of Language Rights”: Ukrainian context], [v:] „Sotsiolinhvistychni studii”, заг. ред. Л. Ставицької, zb. nauk. prats, Kyiv: Vydavnychyi dim Dmytra Buraho, 2010, s. 51-57.

Azhniuk B.M., Kryterii otsiniuvannia movnoi polityky [Criteria for evaluating language policy], [v:] „Movne zakonodavstvo i movna polityka: Ukraina, Yevropa, svit”, zb. nauk. prats, Kyiv: Vydavnychyi dim Dmytra Buraho, 2019, s. 25-50.

Honcharova M., Rol movy u formuvanni riznovydiv identychnostei [The role of language in the formation of varieties of identities], [v:] „Mova i suspilstvo”, 2015, vyp. 6, s. 60-69.

Demska O., Maltsev E., Movna polityka: pro identychnist i uspishnist u hlobalnomu sviti [Language policy: about identity and success in the global world], [v:] „Mova: klasychne-moderne-postmoderne”, ред. Л. Масенко, zb. nauk, prats, Kyiv: Dukh i litera, 2016, vyp. 2, s. 16-26.

Etnonatsionalna struktura ukrainskoho suspilstva [Ethno-national structure of Ukrainian society], Kyiv: Naukova dumka, 2004.

Kukharuk O.Yu., Osoblyvosti etnichnoi identychnosti predstavnykiv riznykh etnomovnykh hrup ukrainskoho studenstva [Features of ethnic identity of representatives of different ethnolinguistic groups of Ukrainian students], kvalifikatsiina naukova pratsia na pravakh rukopysu, Kyiv 2020.

Liakhovych H.V., Variatsii na temu movnoi identyfikatsii ta movnoi identychnosti: mnozhynnist teoretychnykh interpretatsii [Variations on the theme of linguistic identification and linguistic identity: a plurality of theoretical interpretations], [v:] Elektronnyi resurs: http:// npchdusoc_2015_258_246_16(23.10.2020).

Masenko L.T., Narysy z sotsiolinhvistyky [Essays on sociolinguistics], Kyiv: Vyd. dim „Kyievo-Mohylianska akademiia", 2010.

Matsiuk H., Rozvytok teorii suchasnoi sotsiolinhvistyky: formuvannia zmistu poniattia ,instytutsiinyi movnyi menedzhment" [Development of the theory of modern sociolinguistics: formation of the content of the concept “institutional language management”], [v:], Mova i suspilstvo", 2013, vyp. 4, s. 12-32.

Matsiuk H., Status i funktsii rosiiskoi movy v Rosiiskii Federatsii, na postradianskomu prostori y u sviti: stan i perspektyvy rozvytku [Status and functions of the Russian language in the Russian Federation, in the post-Soviet space and in the world: the state and prospects of development], [v:] „Movne zakonodavstvo i movna polityka: Ukraina, Yevropa, svit”, zb. nauk. prats, Kyiv: Vydavnychyi dim Dmytra Buraho, 2019, s. 213-240.

Medvediev O., Movnyi balans Ukrainy-2 [Language balance of Ukraine-2], Kyiv: b. w., 2010.

Mykhalchuk O., Etnomovna samoidentyfikatsiia: sotsiolinhvistychni parametry i yakisnyi stan [Ethnolinguistic self-identification: sociolinguistic parameters and qualitative state], [v:] „Ukrainske movoznavstvo”, 2015, vyp. 45/1, s. 281-287.

Mykhalchuk O., Etnomovni spilnoty v Ukraini: intehratsiia v zahalnonatsionalnyi kontekst [Ethnolinguistic communities in Ukraine: integration into the national context], [v:] „Movne 
zakonodavstvo i movna polityka: Ukraina, Yevropa, svit”, zb. nauk. prats, Kyiv: Vydavnychyi dim Dmytra Buraho, 2019, s. 307-319.

Ohulchanskyi Yu., Etnichna struktura ukrainskoho suspilstva: uiavni ta diisni problemy [Ethnic structure of Ukrainian society: imaginary and real problems], Kyiv: Vyd. dim „Kyievo-Mohylianska akademiia”, 2008.

Oleksenko R., Sytnyk Yu., Movna identychnist yak zasib samovyznachennia ta samoidentyfikatsii $v$ umovakh posttotalitarnoho suspilstva [Linguistic identity as a means of self-determination and self-identification in a post-totalitarian society], [v:] Elektronnyi resurs: http://nbuv.gov.ua/UJRN/upo_2017_1_4 (25.11.2020).

Radevych-Vynnytskyi Ya.K., Movna skladova natsionalnoho buttia: studii z ukrainskoi linhvonatsiolohii [Linguistic component of national life: studies in Ukrainian linguonationalism], Kyiv; Drohobych: Posvit, 2013.

Rubl B., Kapital rozmaitosty [Creating Diversity Capital], Kyiv: Krytyka, 2007.

Sotsiolohiia: slovnyk terminiv i poniat [Sociology: a dictionary of terms and concepts], uporiad. Bilenkyi Ye.A. ta in., Kyiv: Kondor, 2006.

Cherednychenko O., Natsionalno-movna identychnist u hlobalnomu sviti [National-linguistic identity in the global world], [v:] „Ekolohiia movy i movna polityka v suchasnomu sviti”, ред. Б. Ажнюк та ін., zb. nauk prats, Kyiv: Vydavnychyi dim Dmytra Buraho, 2012, s. $40-50$.

Shumarova N.P., Etnomovna identyfikatsiia z pohliadu sotsiolinhvistyky [Ethnolinguistic identification from the point of view of sociolinguistics], [v:] ,Zhyttia u slovi”, zb. nauk. prats na poshanu akademika V.M. Rusanivskoho, Kyiv: Vydavnychyi dim Dmytra Buraho, 2011, s. 353-359.

Iakubova L., Natsionalni menshyny Ukrainy: poshuky mistsia v modernomu ukrainskomu proekti [National minorities of Ukraine: search for a place in the modern Ukrainian project], [v:] „100-richchia derzhavnoho orhanu z pytan etnopolityky v nezalezhnii Ukraini yak istoriia zakhystu natsionalnykh menshyn: derzhavni instytutsii ta mizhnatsionalni vidnosyny - dosvid vyklyky, zavdannia”, zb. nauk. materialiv, Kyiv: Dukh i litera, 2019, s. 91-113.

Fishman J., Endangered Minority Languages: Prospects for Sociolinguistic Research, [в:] Електронний ресурс: https://citeseerx.ist.psu.edu/viewdoc/download?doi=10.1.1.519.6 918\&rep=rep1\&type $=$ pdf $(25.11 .2020)$.

Labov W. Sociolinguistic Patterns, [в:] Електронний ресурс: https://books.google.com. ua/books/about/Sociolinguistic_Patterns.html?id=hD0PNMu8CfQC\&redir_esc $=y$ (23.11.2020). 
